\title{
PERFORMANCE MOTIVATION OF ELITE ATHLETES, RECREATIONAL ATHLETES AND NON-ATHLETES
}

\author{
Pavel Šmela, Petra Pačesová, Stanislav Kraček, Dan Hájovský \\ Department of Sport Educology and Sport Humanities, Faculty of Physical Education and Sports, \\ Comenius University in Bratislava
}

\begin{abstract}
The aim of the paper is to widen knowledge about motivation of elite, recreational athletes and nonathletes. Participants from the elite athletes group $(n=35,16.7 \pm .70$ years old $)$ were football players of the Slovak national team. Recreational athletes $(\mathrm{n}=31,16.8 \pm .80$ years old) and non-athletes $(\mathrm{n}=29,15.7 \pm .60$ years old) are visiting Grammar School in Zvolen. D-M-V standardized questionnaire was used to determine performance motivation. The Kolmogorov-Smirnov's test disconfirmed the null hypothesis on the normality of data. We used the non-parametric Kruskal-Wallis and Mann-Whitney U tests to determine the statistical significance of the differences. The results showed that there were significant ( $p$.0.01) differences with large effect size $\left(\eta^{2} \geq .14\right)$ in all the three (the performance motives scale, the anxiety inhibiting performance scale and the anxiety supporting performance scale) dimensions among the research groups. The motivation of elite athletes is significantly higher $(\mathrm{p}=.048 ; \mathrm{r}=.25)$ compared to the recreational athletes. Also, compared to the non-athletes, the level of performance motivation is significantly higher $(\mathrm{p}=.002 ; \mathrm{r}=.51)$ in the elite athletes. Based on the results of the study we can formulate the statement that the level of performance motivation is contingent on the level of sport activity.
\end{abstract}

Key words: performance motivation, sport activity, adolescence

DOI 10.1515/afepuc-2017-0012

(C) Acta Facultatis Educationis Physicae Universitatis Comenianae 


\section{Introduction}

We can understand motivation as a process of pursuing action that further leads to the achievement of personal goals or goals of the group (Zinčenko \& Meščerjakova 1996). Performance motivation represents a personality characteristic, a sufficiently stable tendency of a person to achieve the best possible performance (Bedrnová \& Nový 2007). According to Hrabal (1989), two independent needs are the basis of the performance motivation. It is a need for successful performance and the need to avoid failure, which is updated in every situation requiring performance behavior. According to Kačániová (1992), the effort to assert oneself is a part of the performance needs. Through them, the need for autonomy and competence (the need to "understand something", "be somebody" or "someone who knows something") is formed. In general, we can talk about a motivational tendency to "achieve success" and "avoid failure". The study of individual theories clarifies that performance motivation cannot be perceived as a bounded phenomenon with detail individual aspects that create it. The approach of Schuler \& Prochaska (2003) is considered the latest view on the concept of performance motivation. They present it as one of the personal characteristic feature understood in a wider context. This is why performance motivation falls under the dimensions of personality, such as perseverance, dominance, commitment, and trust in success. Křivohlavý (2003) says that success mostly fulfils a strengthening function. It leads to the development of a positive side of personality and to a better quality of life that is essential and determinant for a person in a particular situation. Macák, Hošek and Boroš (In Šerešová 2012) states that the more regular and intense the current psychological conditions are in connection with success, the higher is the stabilized aspiration level of the athletes, which may have a positive effect on their performance, but the deeper and more intense the conflict will be after a failure. The Elliot \& Church (1997) hierarchical motivation model contains three components. Those are mastery-approach, performance-approach and performance-avoidance. Research by Conroya and Elliot (2004), confirmed the validity of the hierarchical model not only in academic environment but also in sport. The eligibility of their trichotomy division as well as the relationships between the different levels of the model was confirmed. The fourth type of goals is based on the 2 × 2 model proposed by Conroy, Elliot \& Coatsworth (2007) avoiding mastery-avoidance. Such an orientation is aimed at not making mistakes and not performing worse than in the past. It may occur, for example, in the perfectionists, or in individuals recovering from injuries, in older athletes trying to maintain performance, or in players trying to "play safely" and not to make mistakes. 


\section{Methods}

The research samples were elite athletes $(n=35,16.7 \pm .7$ years old $)$, members of the Slovak national football team, recreational athletes $(\mathrm{n}=31,16.8 \pm .8$ years old $)$ and non-athletes $(\mathrm{n}=29$, $15.7 \pm .6$ years old) attending L’udovít Štúr Secondary Grammar School in Zvolen.

\section{Performance Motivation Questionnaire (DMV)}

The performance motivation questionnaire contains 52 items, where the respondent evaluates the level of consent to the statement on the Likert scale. The questionnaire consists of three scales: the performance motives scale, the anxiety (weakening) inhibiting performance scale and the anxiety (facilitating) supporting performance scale.

1. The performance motives scale corresponds with the complex and multifaceted nature of the performance motives and consists of four aspects: the aspect of performance behaviour, the aspiration aspect, the aspect of endurance at work, the aspect of time orientation in the future.

2. The anxiety inhibiting performance scale can be described as a recognition of the weakening performance, loss of speed and activation in the states that cause tension in stressful, new and critical situations. In other words, the anxiety inhibiting performance can be characterized as a certain tendency to avoid situations that require a high performance in order not to experience the feeling of failure.

3. The anxiety supporting performance scale is characterized by a link between an average, in other words optimal sense of tension and the mobilization of activity as a favorable condition for a quality performance. In other words, we can define it as an effort to avoid failure.

\section{Statistical Methods}

We used basic mathematical-statistical methods to process the results. We detected normality by using the Kolmogorov-Smirnov test. The Kruskal-Wallis test was used to test the significance of differences between the individual scales of the sample divided into groups according to the sporting activities. The significance of the differences between individual independent samples was tested using the Mann-Whitney $U$ test. The significance level was set at $\alpha \leq .05$ and $\alpha \leq .01$. The importance of the relationship or dependence between two groups was expressed using the coefficient $r$ (Pett 1997). The magnitude of the coefficient $r$ is evaluated in the following ranges: $r \geq .90$ (extremely large dependence, relation), $\mathrm{r}=.70-.90$ (large dependence, relation), $\mathrm{r}=.50-.70$ (medium dependence, relation), $\mathrm{r}=.30-.50$ (low dependence, relation, $\mathrm{r}<.30$ (weak dependence, relation). Effect size, the coefficient $\eta^{2}$, effect size, expresses the effect of the independent variable (sport activity) on the dependent variable (performance motivation). The magnitude of coefficient $\eta 2$ is evaluated according Morse (1999) in the following ranges: $\eta 2 \geq .14$ (large effect), $\eta 2=.06-.14$ 
(medium effect), $\eta 2=.01-.06$ (small effect). For better interpretation, we have presented the results in box-plots.

\section{Results}

\section{Performance motives scale (Figure 1)}

The mean value of the elite athletes in the performance motives scale was $102 \pm 13.2$ points. For the recreational athletes it was $95 \pm 11.6$ points and for the non-athletes $90.4 \pm 10.2$ points. The Kruskal-Wallis test showed statistical significance between $\mathrm{H}(2)=18.372, \mathrm{p}=.000, \eta 2=.206$. The Eta squared assessed the effect size as a large effect. Using the Mann Whitney test, a significant difference between a group of the elite and recreational athletes was recorded $(U=397.0, p=.048, r$ $=.25$ ). The coefficient $\mathrm{r}$ has expressed weak dependence. There also was a statistically significant difference in the performance motives scale between a group of the recreational athletes and nonathletes $(\mathrm{U}=269.0, \mathrm{p}=.008, \mathrm{r}=.35)$. Calculated coefficient $\mathrm{r}$ expressed low dependence. In comparison to the elite athletes and non-athletes in this dimension, we registered a significant difference $(U=205.0 ; p=.000 ; r=.51)$. The effect size of the $r$ coefficient has expressed medium dependence.

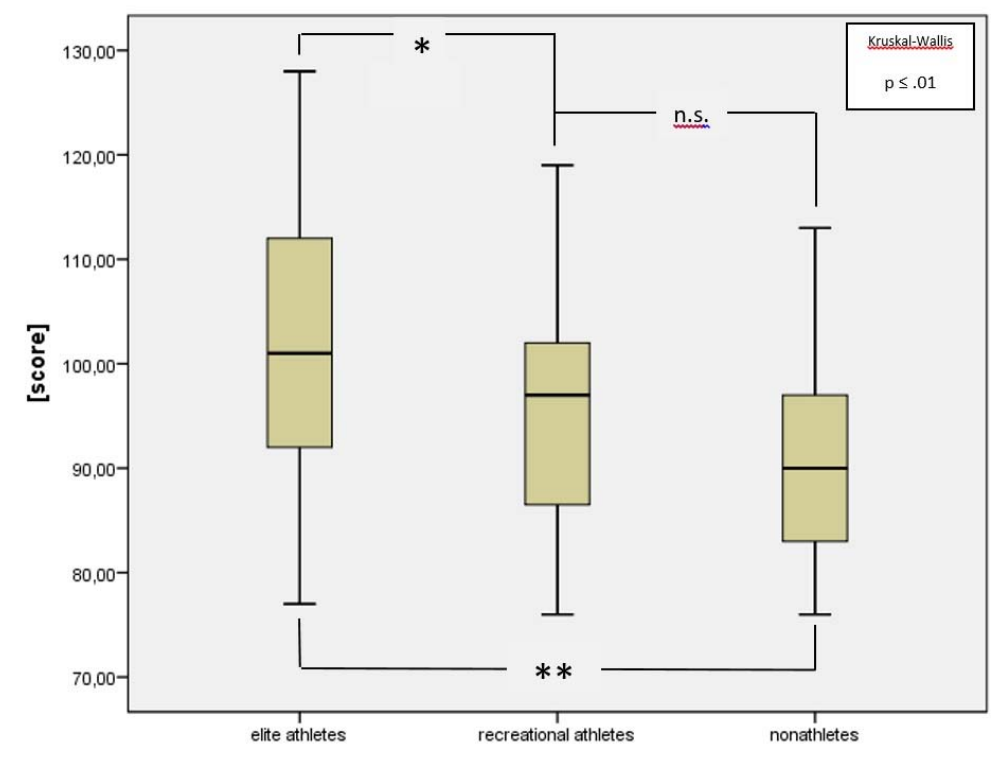

Figure 1

Score of the performance motives scale in elite athletes, recreational athletes and non-athletes

\section{Anxiety supporting performance scale (Figure 2)}

The mean value of the elite athletes in the anxiety supporting performance scale was $35.3 \pm$ 8.2 points, $31.1 \pm 7.6$ points for the recreational athletes and $25.4 \pm 8.2$ points for the non-athletes. The Kruskal-Wallis test values $(H(2)=12.008, p=.002, \eta 2=.146)$ demonstrated a significant 
difference in anxiety supporting performance amongst the individual research groups. Effect size pointed to a big effect. The difference in mean values between the elite athletes and recreational athletes was significant $(\mathrm{U}=386.5, \mathrm{p}=.045, \mathrm{r}=0.25)$. At the $1 \%$ level of statistical significance, the difference between the mean values between the recreational athletes and non-athletes $(\mathrm{U}=269.0$, $\mathrm{p}=.008 ; \mathrm{r}=0.35)$ and between the elite athletes and non-athletes $(\mathrm{U}=209.5, \mathrm{p}=.001, \mathrm{r}=.42)$. Effect size, expressed by the coefficient $r$, speaks of low dependencies.

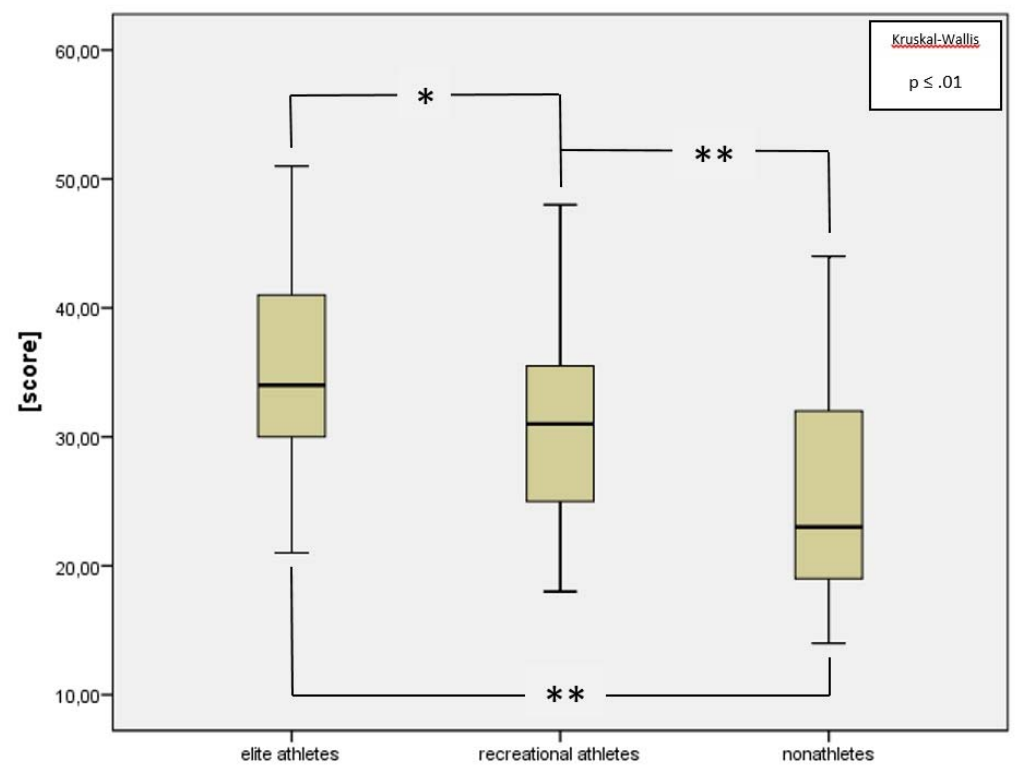

Figure 2

Score of the anxiety supporting performance scale in elite athletes, recreational athletes and non-athletes

\section{Anxiety inhibiting performance scale (Figure 3)}

The mean value in the anxiety inhibiting performance scale of the elite athletes was $30.05 \pm$ 8.0 points, the recreational athletes $36.29 \pm 9.22$ points and $41.17 \pm 12.7$ for the non-athletes. The results of the Kruskal-Wallis test showed a significant difference $(\mathrm{H}(2)=15.508, \mathrm{p}=.000, \eta 2=$ .177) of the mean values between the groups. Effect size was large. The Mann Whiney U test confirmed a significant difference $(\mathrm{U}=330.5, \mathrm{p}=.006, \mathrm{r}=.34)$ between the elite athletes and the recreational athletes. The elite athletes had lower anxiety inhibiting performance compared to the recreational athletes. The difference in mean values of the recreational athletes and the non-athletes was statistically insignificant $(\mathrm{U}=351.0, \mathrm{p}=.145, \mathrm{r}=.19)$. The elite athletes also had significantly $(\mathrm{U}=237.0 ; \mathrm{p}=.000, \mathrm{r}=.46)$ lower anxiety inhibiting performance compared to the non-athletes. 


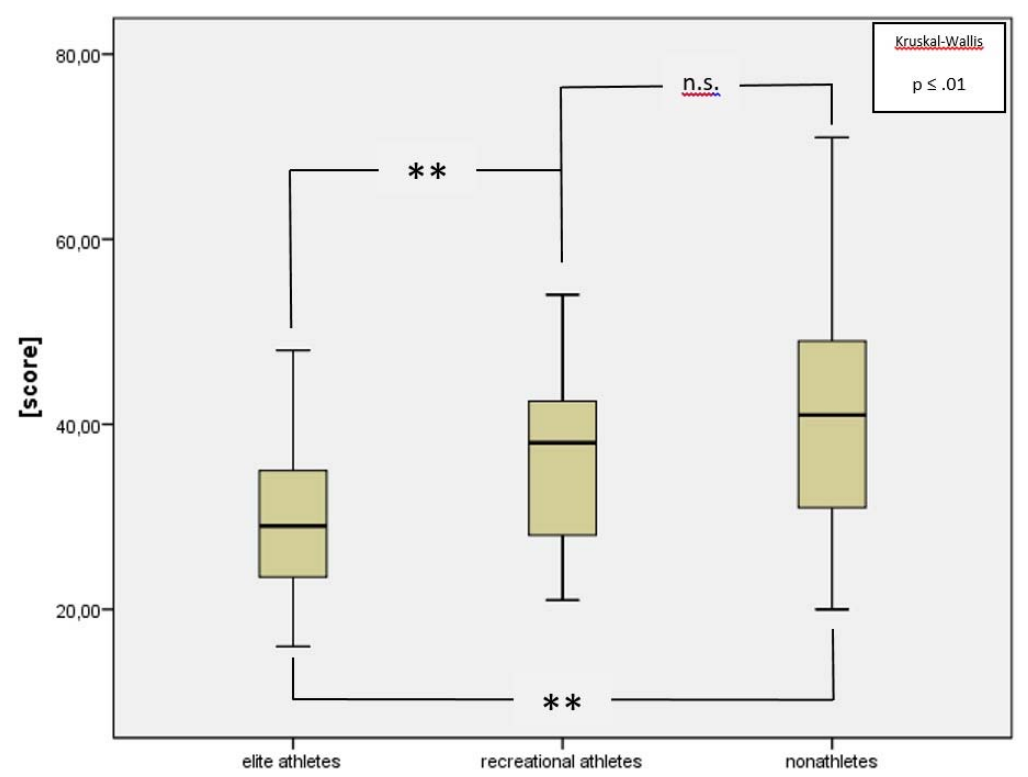

Figure 3

Score of the anxiety inhibiting performance scale in elite athletes, recreational athletes and non-athletes

\section{Discussion}

There are two basic sub-motives in the performance motivation of athletes: hope of success and fear of failure. Athletes can be driven by the desire to perform well and be successful. On the other hand, part of their motivation can also be an effort to avoid failure. The motivation of athletes can acquire various target orientations. According to the concept of performance goals (Grant \& Dweck 2003), performance motivation can include learning goals or performance goals. The athletes, for whom the learning goals are dominant, are constantly trying to improve their abilities. Therefore, they compare their current performances with past or possibly with some objective criteria. The athletes who prefer performance goals try to demonstrate their abilities in front of the others. They try to perform better than the others or not to perform worse than the others. They are therefore more focused on comparing with their competitors. Our research group was composed of respondents aged $16.4 \pm .7$ years. This period can be considered late adolescence in terms of development stages according to Slepička, Hošek \& Hátlová (2011). Performance motivation in adolescence is not constant. This assertion was verified in Castillo et al. (2009) conducting research on 967 Spanish students from various fields of sport. The study found changes in performance motivation in adolescence. The results of their study showed that performance motivation increases significantly in course of adolescence. Another factor that may affect the instability of performance motivation among athletes is the periodization of the training and the competition period during the year. However, Fernandez-Rio et al. (2008) did not notice a significant decrease in performance motivation 
and increase of inhibiting effects during their yearlong research and did not confirm this fact. Pfoff (2015) did research on performance motivation of canoeists and he recorded statistically significant differences between sprint canoeists and average population norms. As well as our research, the author has confirmed the thesis on the higher motivation of performance among elite athletes compared to recreational athletes or non-athletes. Long distance canoeist even had a $10 \%$ higher performance boost compared to sprint canoeists. Kuračka (2008), in his study, presented findings that elite athletes recorded a higher average value on the performance motivation scale, but the difference compared to non-elite sport respondents was not statistically significant. This is where our study differs from the aforementioned. We have recorded significantly higher performance motivation of the elite athletes compared to the non-athletes and recreational athletes. We can explain the variations in the results by possible differences (age, sporting practice, performance level) in the elite athletes' research sample. According to Pardel, Marshalova \& Hrabovska (1992), performance patterns, aspirations, persistence in work and time orientation for the future are included in the performance motives scale. Kuračka (2008) also focused on the correlation of performance motivation with personality characteristics in his research. The results of the work suggest that the performance motives relate in a substantial way to consciousness and anxiety that inhibits performance relates to neuroticism. The "Big Five" scale of consciousness measures the level of the organization and endurance in behavior aimed at a goal, purpose, ambition, hard work (Ruisel \& Halama 2007). The scale of neuroticism, among other things, measures the extent to which people experience fear, feel unease, nervousness, anxiety, and how they deal with stressful situations. Also in these aspects, the nature of anxiety inhibiting performance is implicitly and explicitly present. We can expect a higher performance motives in consciousness people. On the contrary, neuro and emotionally unstable persons should have a higher degree of anxiety inhibiting performance. We can observe these relationships both in groups of the elite athletes and non-athletes. There was recorded no unambiguous pattern of relationships with personality traits in anxiety supporting performance. In the group of the elite athletes, it correlated to the highest level with extroversion and in the group of the non-athletes with neurosis. In sport, therefore, it may not be sufficient to examine what is the level of an individual's performance motivation. It is necessary to work with multiple sub-motives and dimensions of performance motivation. An ultimate sport performance as the ultimate effect of the motivation process is the result of a range of motives that stimulate, maintain, form and strengthen various levels of beginning, process and result of a sport performance (Blahutková \& Pacholík 2008).

\section{Conclusion}

The presented study points to significant $(\mathrm{p} \leq .01)$ differences with a large effect size $(\eta 2 \geq$ $.14)$ in the performance motivation of the elite, recreational athletes and non-athletes. The elite 
athletes, compared to the recreational athletes, have a significantly higher $(\mathrm{p} \leq .05)$ performance motives and anxiety supporting performance. In the performance inhibiting performance scale, the score is significantly lower $(\mathrm{p} \leq .01)$ in favor of the elite athletes. A significantly higher $(\mathrm{p} \leq .01)$ performance motives and anxiety supporting performance or lower anxiety inhibiting performance attain the elite athletes compared to non-athletes. Based on the presented results, sport activity can be considered as one of the factors influencing the motivation to perform. For better work with performance motivation in the training process, we suggest that it is necessary to concentrate more on performance motivation, especially in relation to the personality characteristics of elite athletes, recreational and non-athletes. Further research in this area could focus on more detailed testing of the performance sub-motives in the performance of elite athletes. It would be beneficial to explore the relationship between the individual components of performance motivation and actual performance in terms of individuals and entire teams. In the relationship of these variables we may point to the importance of the effort to achieve success and the need to influence and manage performance motivation in terms of its structure. In elite sport, we mostly deal with the issue how to raise motivation. However, we do not sufficiently emphasize the correct structure of performance motivation. Efforts to limit the fear of failure and to promote the pursuit of success should be evident from the work of sport psychologists, coaches and athletes themselves.

The study was funded by the project of the Ministry of Education, science and research of Slovak Republic VEGA 1/0726/17: Motivačný profil športovania rôznych skupín populácie a vplyv diferencovanej športovej aktivity na zlepšenie subjektívnej dimenzie kvality života.

\section{References}

1. BEDRNOVÁ, E. \& I. NOVÝ et al., 2007. Psychologie a sociologie řizení. Praha: Management Press. ISBN 978-80-7261-169-0.

2. BLAHUTKOVÁ, M. \& V. PACHOLÍK, 2008. Výkonová motivace a vrcholový sport. In: Současný sportovní trénink. Praha: Olympia a ČOV, s. 252-257. ISBN 978-80-7376-079-3.

3. CASTILLO, I., J. L. DUDA, I. BALAGUER \& I. TOMÁS, 2009. Cross domain generality of achievement motivaton across sport and the classroom. In: The case of Spanish adolescent. 44(175), pp. 569-580.

4. CONROY, D. E. \& A. J. ELLIOT, 2004. Fear of failure and achievement goals in sport: Addressing the issue of the chicken and the egg. In: Anxiety, Stress, and Coping. 17(3), pp. 271285. ISBN 978-0-7360-9081-0.

5. CONROY, D. E., A. J. ELLIOT \& J. D. COATSWORTH, 2007. Competence Motivation in Sport and Exercise. In: CHATZISARANTIS, H. (Eds.). Intrinsic Motivation and Self-Determination in 
Exercise and Sport. Champaign, IL: Human Kinetics Publishers, pp. 181-192. ISBN 978-0-73606250-3.

6. ElliOT, A. J. \& M. A. CHURCH, 1997. A Hierarchical Model of Approach and Avoidance Achievement Motivation. In: Journal of Personality and Social Psychology. 72(1), pp. 218-232. ISBN 978-0-8058-6019-1.

7. FERNANDEZ-RIO, J., A. J. CECCHINI ESTRADA, A. MENDEZ-GIMÉNEZ, B. FERNÁNDEZ-GARCIA \& P. SAAVEDRA, 2014. Dominant achievement goal profiles in highlevel swimmers. In: European Journal of Sport Science. 14(3), pp. 265-272.

8. GRANT, H. \& C. S. DWECK, 2003. Clarifying Achievement Goals and Their Impact. In: Journal of Personality and Social Psychology. 85(3), pp. 541-553.

9. HRABAL, V. et al., 1989. Psychologické otázky motivace ve škole. Praha: SPN. ISBN 80-0423487-9.

10. KAČÁNIOVÁ, J., 1992. Psychológia pre učitel'ov. Bratislava: VŠE. ISBN 8022503444.

11. KŘIVOHLAVÝ, J., 2003. Psychologie zdraví. Praha: Portál. ISBN 80-7178551-2.

12. KURAČKA, P., 2008. Vzt’ah medzi výkonovou motiváciou a osobnostnými charakteristikami v rámci modelu ,big five“. Bakalárska práca. Brno: Masarykova univerzita.

13. MORSE, D. T., 1999. Minsize2: A computer program for determining effect size and minimum sample for statistical significance for univariate, multivariate, and nonparametric tests. In: Educational and Psychological Measurement. 59(3), pp. 518-531.

14. PARDEL, T., L. MARŠÁLOVÁ \& A. HRABOVSKÁ, 1992. Dotazník motivácie výkonu. Bratislava: Psychodiagnostika.

15. PETT, M. A., 1997. Nonparametric statistics for health care research: Statistics for small samples and unusual distributions. Thousand Oaks, CA: Sage. IBN 978-1-4522-8196-4.

16. PFOFF, M., 2015. Temperamentové vlastnosti a výkonová motivace závodniků v rychlostní kanoistice. Diplomová práca. Praha: Karlova Univerzita.

17. RUISEL, I. \& P. HALAMA, 2007. NEO-FFI. NEO pätfaktorový osobnostný inventár. Praha: Testcentrum-Hogrefe.

18. SCHULER, H. \& M. PROCHASKA, 2003. Dotazník motivace k výkonu-DMI-príručka. Praha: Testcentrum Praha.

19. SLEPIČKA, P., V. HOŠEK \& B. HÁTLOVÁ, 2011. Psychologie sportu. Praha: Karolinum.

20. ŠEREŠOVÁ, E., 2012. Záujmy, motivácia a výkonová motivácia v osobnosti športovca. In: Acta Facultatis Iuridicae Universitatis Comenianae XXX. Bratislava: Univerzita Komenského v Bratislave vo Vydavatel'stve UK, pp. 103-111. ISBN 978-80-223-3282-8.

21. ZINČENKO, V. P. \& B. G. MEŠČERJAKOVA, 1996. Psychologičeskij slovar. Moskva: Pedagogika - Press. 